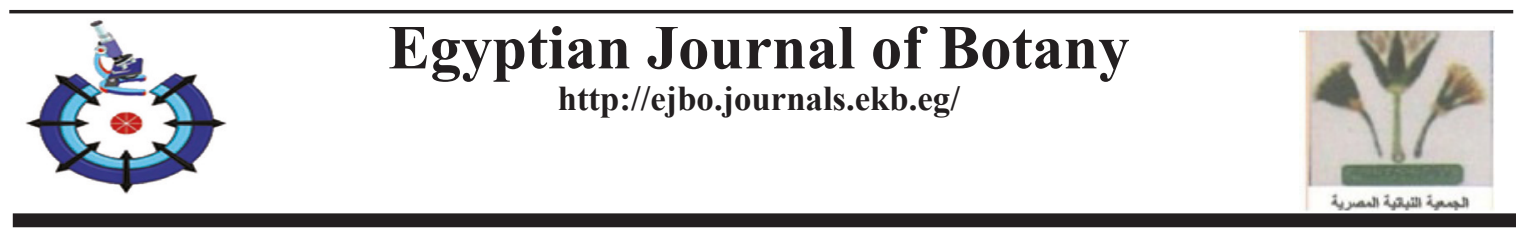

\title{
Biocontrol of Wilt-Inducing Fusarium oxysporum by Aqueous Leaf Extract from Egyptian Ammi majus and Ammi visnaga
}

Reyad Mohamed El-Sharkawy ${ }^{(1)}$, Hamed Mohamed El-Shora ${ }^{(2) \#}$

(1) Botany and Microbiology Department, Faculty of Science, Benha University, Al

Qaliobia, Egypt; (2)Botany Department, Faculty of Science, Mansoura University,

Dakahlia, Egypt.

\begin{abstract}
GUSARIUM oxysporum causes wilt disease of tomato crop. Fungal management using fungicides results in several problems in the enviroment. Plant metabolites represent an alternative method since they have minute impact on the enviroment. The present investigation is an attempt to develop eco-friendly management of $F$. oxysporum using aqueous leaf extract of Ammi majus and Ammi visnaga (Family: Apiaceae). Treating the fungus with aqueous leaf extract from the two species of Ammi plants resulted in the inhibition of the fungal growth. Ammi leaf extracts inhibited the activities of metabolic enzymes including glucose-6-phosphate dehydrogenase (G-6-PD, EC: 1.1.1.49), glutamine synthetase (GS, EC: 6.3.1.2) and nitrate reductase (NR, EC: 1.7.99.4) but increased L-phenylalanine ammonia lyase (PAL, EC: 4.3.1.5) activities of F.oxysporum. Both of the total amino acids and the total soluble protein contents of F. oxysporum were reduced under the same treatment. The leaf extracts inhibited the activities of the enzymes which are involved in pathogenicity including pectinase (EC 3.2.1.15), protease (EC: 3.4.21.14), cellulase (EC: 3.2.1.4) and xylanase (EC: 3.2.1.8). $\mathrm{IC}_{50}$ values for the four enzymes were $93.32,69.03,71.27$ and $74.93 \mathrm{mg} / \mathrm{ml}$, respectively. However, $\mathrm{IC}_{50}$ values were $134.22,106.31,90.65$ and $100.26 \mathrm{mgml}^{-1}$ for the four enzymes in the same order under treatment with $A$. visnaga leaf extract. The total phenols and total flavonoids in leaf extracts from the two Ammi species were determined and they were higher in A. majus than those of A.visnaga. This study suggests efficiency of Ammi leaf extracts in suppression of Fusarium oxysporum pathogenicity.
\end{abstract}

Keywords: Ammi majus, Ammi visnaga, Fusarium oxysporum, Enzymes activities, Flavonoids, Phenolics.

\section{Introduction}

The major challenge in the production of plant crops, vegetables and fruits is the susceptibility of the various plants toward different plant pathogens. Fungi, viruses, bacteria as well as nematodes represent the main causal pathogens of several plant diseases. The parasitic fungi are the most sever plant pathogens and account about $90 \%$ of economic loss in agriculture (Gupta \& Sharma, 2008; Maninegalai et al., 2011).

F. oxysporum is a soil-borne microflora which causes a wilt disease in various plant crops and in particular tomato. This soil-borne fungus may be presented as pathogenic and nonpathogenic strains in soil rhizosphere and are competing with each other. The wilt inducing Fusarium strains are considered as hindrance in the production of various economically important plants (Srinivas et al., 2019).

The sever disease may be due to a combination of many factors including production of pathogenesis related enzymes, reaching of fungal mycelium in vascular bundle, antibiosis and

\#Corresponding author email: shoraem@yahoo.com

Received 8/12/2019; Accepted 20/1/2020

DOI : 10.21608/ejbo.2020.20709.1409

Edited by:Prof. Dr. Salama A. Ouf, Faculty of Science, Cairo University, Giza 12613, Egypt.

(C)2020 National Information and Documentation Center (NIDOC) 
deficiency of nutrients in rhizosphere (Goel \& Sharma, 2016; Srinivas et al., 2019).

Plant pathogenic fungi are capable to produce various cell wall degrading enzymes (CWDE) that facilitate their passage through different plant cell barriers. Different CWDE play a vital role in the pathogenesis of different fungi by deploymerizing the major components of the cell wall of plant (Kubicek et al., 2014). In response, production of different protein inhibitors by host plant is a defense way against several phytopathogens (Juge, 2006).

Several biocontrol approaches including medicinal plant extract, fungicides and utilization of resistant breeding are relevant. The performance of synthetic fungicides to soil causes violent contamination to the environment. Therefore, the biocontrol of fungal diseases using various plant extracts is of excellent interest (Kilani-Jaziri et al., 2011; Rongai et al., 2012; Dwivedi \& Sangeeta, 2015).

Plants develop several compounds that are able to inhibit microbial enzymes and cause impairment of the fungal cell wall (Polya, 2003; Mostafa et al., 2009; Goel \& Sharma, 2016). Ammi plants are one of important medicinal plants belonging to family Apiaceae and they are widely distributed in Egypt. Several secondary metabolites of significant and numerious biological activities were found in Ammi plants such as coumarins, phenols, flavonoids and others (Al-Snafi, 2013; Aourabi et al., 2019). These compounds are used as crucial health care. The application of Ammi extracts in the biocontrol of many plant pathogens is of great importance (Hashim et al., 2014; Hussein et al., 2016; Adham \& Abdula, 2017).

The present work aimed to study the influence of leaf extract from Ammi majus and $A$. visnaga on growth of $F$. oxysporum and on the activities of some metabolic enzymes such as glucose-6-phosphate dehydrogenase (G6PD), L-phenylalanine ammonia lyase (PAL), glutamine synthetase (GS) and nitrate reductase (NR) of F. oxysporum. Also, it was aimed to test the influence of Ammi leaf extracts on the activities of pathogenicity related enzymes including pectinase, protease, cellulase and xylanase. In addition, it was designed to explore the influence of the leaf extracts on amino acids and protein contents of $F$. oxysporum.

\section{Materials and Methods}

\section{Fungal isolate}

Fusarium oxysporum used in the present study was provided by Prof. Metwally A. Metwally, Professor of Microbiology, Botany Department, Faculty of Science, Tanta University. Fungal culture was grown on Czapek's-Dox agar containing \% (sucrose, 3.0; $\mathrm{NaNO}_{3} 0.2 ; \mathrm{K}_{2} \mathrm{HPO}_{4}$, $0.1 ; \mathrm{FeSO}_{4} .7 \mathrm{H}_{2} \mathrm{O}, 0.1 ; \mathrm{KCl}, 0.05$ and $\mathrm{MgSO}_{4}$ $7 \mathrm{H}_{2} \mathrm{O}, 0.5$ and $\mathrm{pH} 7.0$ ) at $28^{\circ} \mathrm{C}$ for 5 days and was sub-cultured periodically for extended periods of storage.

Preparation of aqueous leaf extracts of Ammi plants

Collection of Ammi plants

A. majus and A.visnaga were collected from different locations in Egypt and identified by Prof. Dr. El-Sayed F. El-Halwany, Professor of Plant Ecology, Botany Department, Faculty of Science, Mansoura University. plants

Preparation of aqueous leaf extracts of Ammi

Preparation of aqueous leaf extract is based on the method of El-Shora et al. (2016). Leaves from each of $A$. majus and A. visnaga were collected and washed carefully under tap water then by distilled water. The collected leaves were air-dried and homogenously grinded using mechanical grinder to prepare fine powder. The powder $(10 \% \mathrm{w} / \mathrm{v})$ was soaked in sterilized distilled water and put on a shaker with a speed of $120 \mathrm{rpm}$ for $24 \mathrm{hrs}$ at room temperature $\left(20 \pm 2^{\circ} \mathrm{C}\right)$. The resulting mixtures were filtered using Whatman number 1 filter paper then centrifuged for $20 \mathrm{~min}$ at $10,000 \mathrm{~g}$ to remove particulate materials. The resulted extracts were concentrated and then dried in lyophilizer. The dried extracts were collected in air tight containers and stored at room temperature for further use.

Extraction yield $(\%)=$ [dry wt. of dried extract/ dry wt. of sample] x 100

Effect of Ammi leaf extracts on mycelium growth

The mycelium growth of $F$. oxysporum was evaluated in Petridishes $(60 \mathrm{~mm})$ filled with PDA medium amended with various concentrations ( 0 $50 \mathrm{mg} / \mathrm{ml}$ ) of aqueous leaf extract of A. majus or $A$. visnaga. Next, the Petri dishs were inoculated with $5 \mathrm{~mm}$ diameter disc of fungal mycelium 
which was taken from 7-day old pure culture. All dishes were incubated for 6 days at $25^{\circ} \mathrm{C}$. After that, the mycelial growth was measured 6 days after inoculation. For each treatment, three replicates were maintained. Finally, the antifungal activity was expressed in terms of the inhibition percentage according to the following equation:

Fungal inhibition $(\%)=(R c-R t) / R c \times 100$

where: $R c$ is the mean value of $F$. oxysporum radial growth in control and $R t$ is the mean value of fungal radial growth in plant extract treated plates.

Growth of F. oxysporum on modified Richard's liquid medium

Aqueous leaf extracts from dried A. majus or A. visnaga leaves was diluted to attain various concentrations $(10,20,30,40$ and $50 \mathrm{mg} / \mathrm{ml})$ by mixing with sterilized modified Richard's liquid medium contained $(\mathrm{g} / \mathrm{L}): \mathrm{MgSO}_{4} \cdot 7 \mathrm{H}_{2} \mathrm{O}$, 2.5; $\mathrm{KH}_{2} \mathrm{PO}_{4}, 5 ; \mathrm{KNO}_{3}, 10 ; \mathrm{FeCl}_{3} .6 \mathrm{H}_{2} \mathrm{O}, 0.02$ supplemented with the substrate of the assayed enzyme (Zhang et al., 2014; Xue et al., 2018). Spore suspension of $F$. oxysporum $\left(10^{5} \mathrm{spores} / \mathrm{ml}\right)$ was inoculated into the broth medium and then incubated for 5 days at $28^{\circ} \mathrm{C}$ on an orbital shaker (180rpm).

\section{Preparation of the mycelial extract}

After the incubation period (5 days) the fungal mycelium was collected, washed and then homogenized for $30 \mathrm{~min}$ in a homogenizer using $50 \mathrm{mM}$ phosphate buffer ( $\mathrm{pH} 6.0$ ). The resulting homogenate was centrifuged at $12,000 \mathrm{~g}$ for $15 \mathrm{~min}$ at $4^{\circ} \mathrm{C}$ and the supernatant represented the mycelial extract which was stored at $-20^{\circ} \mathrm{C}$. This supernatant was used for determination of metabolic enzymes activities, the total amino acids and total protein content. Broth medium without plant extract was used as control under the same conditions.

Assays of metabolic enzymes activities in mycelial
extracts
Glucose-6-phosphate dehydrogenase (G6PD)
activity
G6PD activity was assayed according to Betke et al. (1967). This method depends on measuring the production of NADPH spectrophotometrically at $340 \mathrm{~nm}$. The reaction medium of $3 \mathrm{ml}$ included $0.5 \mathrm{ml}$ of $0.6 \mathrm{mM} \mathrm{G} 6 \mathrm{P}, 0.5 \mathrm{ml}$ of $0.2 \mathrm{mM}$ of NADP and $1.5 \mathrm{ml}$ of $10 \mathrm{mM} \mathrm{MgCl}$ in $150 \mathrm{mM}$ Tris- $\mathrm{HCl}$ buffer (pH 8.0). Enzyme preparation $(0.3 \mathrm{ml})$ was added to start the reaction and kept at $30^{\circ} \mathrm{C} 15 \mathrm{~min}$. One unit (U) of G6PD activity is defined as the amount of G6PD which preduces one $\mu$ mole of NADP per min under standard assay conditions.

\section{L-phenylalanine ammonia-lyase activity}

The assay of L-phenylalanine ammonialyase (PAL) activity was carried out by the method adopted by Chen et al. (2006). In $3 \mathrm{ml}$, the reaction mixture composed of $0.2 \mathrm{ml}$ of $0.5 \mathrm{mM}$ L-phenylalanine, $1.5 \mathrm{ml}$ of $50 \mathrm{mM}$ Tris- $\mathrm{HCl}$ buffer $(\mathrm{pH} 8.9), 0.8 \mathrm{ml}$ of $3.6 \mathrm{mM} \mathrm{NaCl}$ and $0.5 \mathrm{ml}$ of the mycelial extract (crude enzyme). The reaction mixture was incubated at $37^{\circ} \mathrm{C}$ for $1 \mathrm{hrs}$ and was terminated using $0.5 \mathrm{ml}$ of $35 \% \quad(\mathrm{w} / \mathrm{v})$ trifluoroacetic acid (TFA). The mixture was centrifuged for $5 \mathrm{~min}$ at $5,000 \mathrm{~g}$ to pellet the denaturated protein. The cinnamic acid was estimated spectrophotometrically by measuring the absorbance at $290 \mathrm{~nm}$. One unit (U) was expressed as the amount of PAL required to catalyze the conversion of one $\mu$ mol of L-phenylalanine per min.

\section{Glutamine synthetase (GS) activity}

GS was assayed by the method adopted by ElShora \& Khalaf (2008) and El-Shora \& Ali (2011). The assay mixture contained in $3 \mathrm{ml}: 50 \mathrm{mM}$ imidazole- $\mathrm{HCl}(\mathrm{pH} 7.0), 55 \mathrm{mM}$ L-glutamate, $3 \mathrm{mM}$ ATP, $15 \mathrm{mM} \mathrm{MgCl}_{2}, 30 \mathrm{mM} \mathrm{NH}_{4} \mathrm{Cl}$ and $0.5 \mathrm{ml}$ enzyme extract. The starting of the reaction was intiated by enzyme extract and the incubation at $30^{\circ} \mathrm{C}$. The reaction was terminated by $5 \mathrm{ml}$ freshly prepared $\mathrm{FeSO}_{4} .7 \mathrm{H}_{2} \mathrm{O}(0.8 \%$ in $0.015 \mathrm{~N}$ $\mathrm{H}_{2} \mathrm{SO}_{4}$,) after $15 \mathrm{~min}$. The produced inorganic phosphate $(\mathrm{Pi})$ was estimated by $0.5 \mathrm{ml}$ of $6.6 \%$ ammonium molbedate. The absorbance was recorded spectrophotometrically at $600 \mathrm{~nm}$.

Nitrate reductase (NR)

NR was assayed according to Evans \& Nason (1953). One ml Tris buffer-enzyme extract was mixed with $0.5 \mathrm{ml}$ of $100 \mathrm{mM} \mathrm{KNO}_{3}$ and incubated for $5 \mathrm{~min}$ at $30^{\circ} \mathrm{C}$. The enzyme reaction was initated by $5 \mathrm{ml}$ of $0.5 \mu \mathrm{M}$ NADPH and kept for $15 \mathrm{~min}$ at $30^{\circ} \mathrm{C}$. The enzyme reaction was terminated by $0.3 \mathrm{ml}$ of $100 \mathrm{mM} \mathrm{ZnSO}_{4} \cdot 6 \mathrm{H}_{2} \mathrm{O}$ followed by $1 \mathrm{ml}$ of absolute ethanol.

A sample $(0.2 \mathrm{ml})$ of the assay mixture was added to $1.0 \mathrm{ml}$ of $1.0 \%$ sulphanilamide dichloride in distilled water. The resulting pink color from diazotization was left for developing for $20 \mathrm{~min}$. 
The volume was raised up to $5.0 \mathrm{ml}$ using distilled water. The absorbance was recorded at $540 \mathrm{~nm}$ spetrophotometerically. Sodium nitrite solution was using for preparing standard curve.

Influence of aqueous leaf extracts on total free amino acid of $F$. oxysporum

The total free amino acid of $F$. oxysporum was estimated by ninhydrin method according to Moore \& Stein (1948). One $\mathrm{ml}$ of the sample was added to one $\mathrm{ml}$ of ninhydrin solution and then left for $15 \mathrm{~min}$ in boiling water bath. Add $5 \mathrm{ml}$ of diluent (water $+n$-propanol in equal volume) and incubate for $15 \mathrm{~min}$ at Lab temperature. The absorbance was recorded spectrophotometrically at $570 \mathrm{~nm}$. The estimation was done in triplicates and the results were expressed as $\mathrm{mgg}^{-1}$ sample.

Influence of aqueous leaf extracts on total soluble protein content of $F$. oxysporum

The total soluble protein of $F$. oxysporum was determined according to Bradford (1976). About $50 \mu \mathrm{l}$ of mycelial extract was made up to $100 \mu 1$ with $150 \mathrm{mM} \mathrm{NaCl}$ in a test tube. One $\mathrm{ml}$ of Bradford's reagent was added and mixed well. The absorbance was read at $595 \mathrm{~nm}$ spectrophotometrically. Bovine serum albumin (BSA) was used as standard (Bradford, 1976).

Influence of leaf extracts on the activities of pathogenesis related enzymes

F. oxysporum $\left(10^{5}\right.$ spores $\left./ \mathrm{ml}\right)$ was grown on modified Richard's liquid medium amended with different concentrations $(0-50 \mathrm{mg} / \mathrm{ml})$ of leaf extract from $A$. majus or $A$. visnaga and specific enzyme substrate as the sole carbon source for each investigated enzyme. Flasks were incubated on an orbital shaker (180rpm) at $28^{\circ} \mathrm{C}$ for 5 days. After the incubation time, the mycelial pellets were collected through filtration using Whatman filter paper No. 1 (Whatman, Piscataway, NJ, USA) and discarded. The filtrate was centrifuged at $12,000 \mathrm{~g}$ for $15 \mathrm{~min}$ at $4^{\circ} \mathrm{C}$ and the supernatant was collected and stored at $-20^{\circ} \mathrm{C}$ as the crude extract of extracellular enzymes for determination of pathogenicity related enzymes activities (Zhang et al., 2014; Xue et al., 2018).

Assay of pectinase activity

Polygalacturonase activity was assayed according to Aguillar \& Huitron (1990). A sample of $0.1 \mathrm{ml}$ of enzyme preparation was incubated with $0.1 \mathrm{ml}$ of polygalacturonic acid (PGA, $1.0 \%$, $\mathrm{w} / \mathrm{v}$ ) for $10 \mathrm{~min}$ at $40^{\circ} \mathrm{C}$. After adding $0.4 \mathrm{ml}$ of dinitrosalicylic acid reagent (DNSA), the assay medium was boiled for $10 \mathrm{~min}$. The mixture was finally made up to $5 \mathrm{ml}$ using $4.4 \mathrm{ml}$ distilled water. The absorbance was recorded at $530 \mathrm{~nm}$ spectrophotometrically. One unit (U) was defined as the amount of enzyme which catalyzes the formation of one $\mu \mathrm{mol}$ of galacturonic acid per $\min$.

\section{Assay of protease activity}

Protease assay was carried out by the adopted method of El-Shora \& Metwally (2008) and ElShora et al. (2016). A sample $(2.5 \mathrm{ml})$ of casein solution $(0.65 \%)$ prepared in $100 \mathrm{mM}$ Tris- $\mathrm{HCl}$ buffer ( $\mathrm{pH} 8.5$ ) was mixed with $0.5 \mathrm{ml}$ enzyme extract. The reaction was kept for $10 \mathrm{~min}$ at $37^{\circ} \mathrm{C}$. After the incubation time, the reaction was terminated by $2 \mathrm{ml}$ of $120 \mathrm{mM}$ trichloroacetic acid (TCA). The mixture was held in water bath for $20 \mathrm{~min}$ at $37^{\circ} \mathrm{C}$ and then centrifuged for $15 \mathrm{~min}$ at $12,000 \mathrm{~g}$. One $\mathrm{ml}$ of the resulting supernatant was added to $2.5 \mathrm{ml}$ of $500 \mathrm{mM} \mathrm{Na}_{2} \mathrm{CO}_{3}$ and $0.5 \mathrm{ml}$ of Folin-Ciocalteu reagent. The mixture was left at $37^{\circ} \mathrm{C}$ for $25 \mathrm{~min}$. The absorbance was recorded at $660 \mathrm{~nm}$. One unit $(\mathrm{U})$ was defined as the amount of protease which liberates $1 \mu \mathrm{gmin}^{-1}$ tyrosine at $37^{\circ} \mathrm{C}$ and $\mathrm{pH}$ 8.5. Tyrosin was used for preparation of standard curve.

\section{Assay of cellulase activity}

The assay of cellulase activity was carried out by estimating the reducing sugar released from carboxymethyl cellulose (CMC) using dinitrosalicylic acid reagent (Goel et al., 2019). Enzyme preparation $(0.5 \mathrm{ml})$ was mixed with $0.5 \mathrm{ml}$ $1 \% \mathrm{CMC}$ in $50 \mathrm{mM}$ phosphate buffer ( $\mathrm{pH} 7.0)$. The mixture was incubated for at $30^{\circ} \mathrm{C} 30 \mathrm{~min}$. The reaction was boiled for $15 \mathrm{~min}$ at $100^{\circ} \mathrm{C}$ in a water bath followed by adding $3 \mathrm{ml}$ of dinitrosalicylic acid. The absorbance was recorded at $540 \mathrm{~nm}$ spectrophotometrically to estimate the enzyme activity using glucose standard curve.

\section{Assay of xylanase activity}

The assay of xylanase activity was performed by the adopted method of Bailey et al. (1992). The assay medium contained $0.9 \mathrm{ml}$ of xylose $(1 \%$ $\mathrm{w} / \mathrm{v})$ in $50 \mathrm{mM}$ citrate buffer $(\mathrm{pH} 5.0)$ and $0.5 \mathrm{ml}$ of enzyme preparation followed by incubation at $30^{\circ} \mathrm{C}$ for $20 \mathrm{~min}$. The mixture was boiled at $100^{\circ} \mathrm{C}$ for $10 \mathrm{~min}$ and then $1 \mathrm{ml}$ of dinitrosalicylic acid reagent was added to terminate the reaction. After cooling, the absorbance was recorded spectrophotometrically at $540 \mathrm{~nm}$ using standard curve of xylose and the results were expressed in 
terms of one $\mu \mathrm{mol}$ of reducing sugar produced per $\min$.

Determination of total phenolic content in leaf extracts of Ammi plants

The total phenolic content of $A$. majus and $A$. visnaga extract was estimated by the adopted metod of Kaur \& Kapoor (2002). The reaction medium contained $0.5 \mathrm{ml}$ plant leaf extract or gallic acid mixed with $2.5 \mathrm{ml}$ distilled water as well as $0.25 \mathrm{ml}$ of $2 \mathrm{~N}$ Folin-Ciocalteu reagent for $5 \mathrm{~min}$. Aqueous $\mathrm{Na}_{2} \mathrm{CO}_{3}(0.75 \mathrm{ml}, 20 \% \mathrm{w} / \mathrm{v})$ was then added with $0.95 \mathrm{ml}$ distilled water and incubated for $1 \mathrm{hr}$ in dark at $37^{\circ} \mathrm{C}$. The absorbance was recorded at $765 \mathrm{~nm}$. Gallic acid (GA) was used as a standard and the results were expressed as mg GA g ${ }^{-1}$ dry weight.

Determination of total flavonoid content in leaf extracts of Ammi plants

The total flavonoid of leaf extracts from $A$. majus and $A$. visnaga was determined by the adopted method of Gulati et al. (2012). A sample of leaf extract $(0.5 \mathrm{ml})$ was raised up to $1.0 \mathrm{ml}$ using distilled water, followed by $0.3 \mathrm{ml} \mathrm{NaNO}_{2}$ $(5 \%)$ and $0.3 \mathrm{ml}$ aluminum chloride $(10 \%)$. The mixture was mixed and incubated for $10 \mathrm{~min}$ at $25^{\circ} \mathrm{C}$ and then $2 \mathrm{ml}$ of $1 \mathrm{M} \mathrm{NaOH}$ were added. The final volume of the reaction was made up to $10 \mathrm{ml}$ with distilled water. The absorbance was recorded at $510 \mathrm{~nm}$ after $5 \mathrm{~min}$. Quercetin was used as standard and the results are calculated as mg quercetin equivalent (QE) $\mathrm{g}^{-1}$ dry weight.

\section{Statistical analysis}

All the experiments were done in triplicate and their mean values were presented with the standard deviation (S.D.).

\section{Results and Discussion}

Aqueous leaf extract was prepared from each of $A$. majus and $A$. visnaga as described in Materials and Methods. The extraction yield of this process was $17 \%$. The antifungal activity of leaf extract from $A$. majus and $A$. visnaga against $F$. oxysporum was carried out using agar plate assay and presented in Fig.1. The results reveal the capability of aqueous leaf extract from both species of Ammi plants to reduce the fungal radial growth and the reduction was dependent on the extract concentration.

The reduction in mycelial growth of $F$. oxysporum by aqueous leaf extract of $A$. majus and $A$. visnaga was about $93 \%$ and $74 \%$, respectively at $50 \%$ concentration. Anti-mycotic activity of Ammi leaf extracts was associated with low content of total amino acids as well as the total soluble protein. Dwivedi \& Sangeeta (2015) reported the capability of aqueous extract from four medicinal plants at various concentrations to decrease the radial growth of $F$. oxysporum. The antimicrobial activity of $A$. majus and $A$. visnaga extracts was reported by Belkacem et al. (2016) and Al-Hadhrami et al. (2016). The antifungal potentiality of various medicinal plants was attributed to their phenolic and flavonoids contents (Shankaracharya et al., 2000; Hadizadeh et al., 2009; Singh et al., 2013). Ammi species

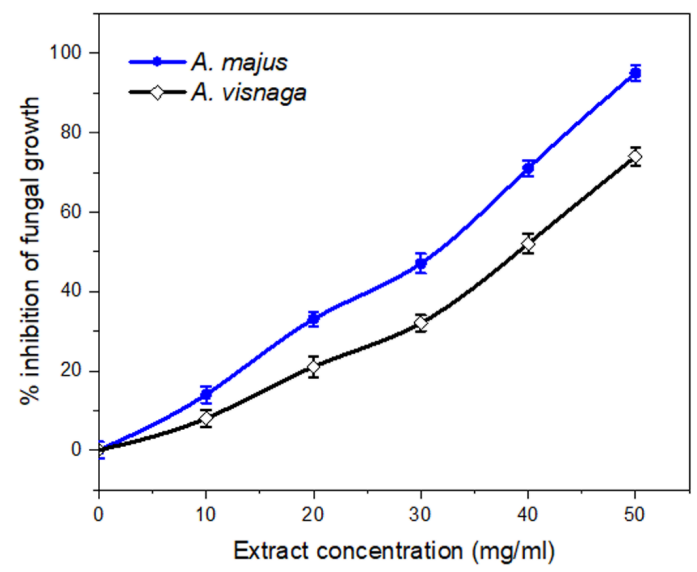

Fig. 1. Susceptibility of F.oxysporum radial growth to aqueous leaf extract of $A$. majus and $A$. visnaga at different concentrations.

contain various bioactive compounds (mainly coumarins, phenols and flavonoids) which are of important biological activities (Al-Snafi, 2013).

Several enzymes are involved in the physiological processes and pathogenesis of fungi. The inhibitory effect of leaf extracts from A. majus (Fig. 2A) and A. visnaga (Fig. 2B) on fungal enzymes activities of $F$. oxysporum was investigated. The production of G6PD, GS and NR by $F$. oxysporum was inhibited by the aqueous leaf extracts from both plant species and the inihibition was concentration-dependent. On the other hand, PAL activity of $F$. oxysporum increased in concentration-dependent manner by leaf extract of both Ammi species.

Fu et al. (2018) and Chamizo-Ampudia et al. (2017) reported that NR in different microorganisms is the key enzyme in nitrogen 
assimilation. Cytosolic-NR catalyzes the conversion of nitrate into nitrite, followed by the reduction of $\mathrm{NO}_{2}^{-}$into $\mathrm{NH}_{4}^{+}$for amino acid biosynthesis (Kolbert et al., 2008; Stéphanie \& Dimah, 2009). Processes of nitrate reduction and glutamate formation require various reductants which supplied by G6PD. In addition, Hall \& Tomsett (2000) reported that NADPH is the electron donor for NR in fungi. Therefore, the results confirm the correlation between reduction of G6PD production and NR activity. The
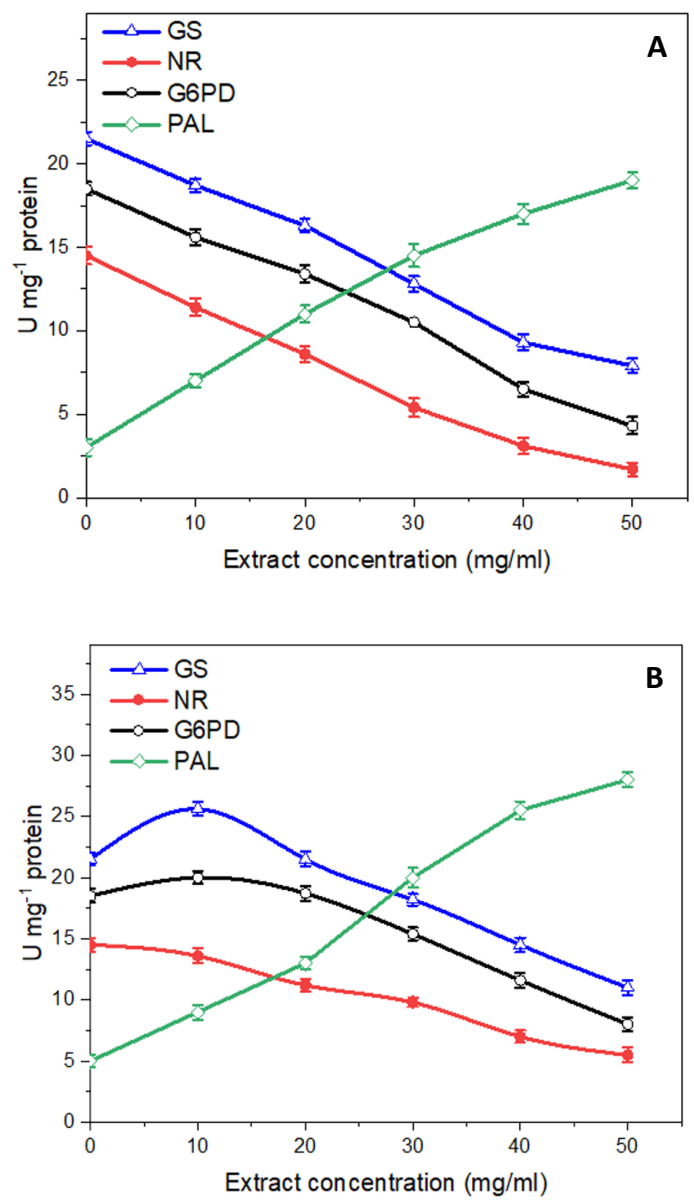

Fig. 2. Influence of aqueous leaf extracts from $A$. majus (A) and $A$. visnaga (B) on metabolic enzymes of $F$. oxysporum.

deactivation of NR caused reduction of nitric oxide level and amino acid production by some pathogens and consequently reduction of fungal growth (Yamamoto-Katou et al., 2006).

GS is a major regulatory enzyme in ATPdependent assimilation of ammonium with glutamate (Zhang et al., 2016). The obtained glutamine was then incorporated with specific amino acids, producing precursors for other amino acids, proteins and nitrogen-containing compounds (Forde \& Lea, 2007). It has been reported that inhibition of GS results in reduction of Aspergillus nidulans growth (Macheda et al., 1999).

Hyun et al. (2011) reported the presence of PAL in various ascomycetes, deuteromycetes and basidiomycetes. Different fungi can utilize the amino acid phenylalanine through various metabolic pathways involved in the deamination process to cinnamic acid. The function of PAL in fungi is to obtain the requirements of nitrogen and carbon from amino acids. It was suggested that PAL activity is vital in secondary metabolism and pathogenesis and the increase of PAL activity by the Ammi leaf extractsis in agreement with report of Gholamnezhad (2019).

PAL activity was increased under treatment with Ammi leaf extracts to convert the primary metabolites to defensive metabolites for scavenging the reactive oxygen species (ROS) produced within the fungal mycelium due to the chemical stress resulted by Ammi leaf extracts which contain various chemical compounds responsible for such stress (Kaboodi et al., 2016). Among these chemicals found in Ammi extracts are coumarins, flavonoids, tannins, anthraquinones, saponin and terpenoids (Zaher et al., 2019).

The total amino acids (Fig. 3A) and total soluble protein (Fig. 3B) of $F$. oxysporum were remarkably declined with increasing concentration of the aqueous leaf extracts from $A$. majus and $A$. visnaga. Leaf extract of $A$. majus was more effective in reducing the total amino acids as well as the total soluble protein of $F$. oxysporum than that of $A$. visnaga. Phenolics from plant parts were reported to be the main reason for inhibition of protein synthesis by fungi and the occurrence of sever pathogenesis (Nateqi \& Mirghazanfari, 2018).

Fungi produce the various enzymes to depolymerize the major polysaccharides in the plant cell wall includinig pectin, cellulose and hemicellulose (Kubicek et al., 2014). The extracellular fungal enzymes are efficient in the degradation of the structure barriers of plant cell and hence facilitate the penetration and invasion of host cells (Walton, 1994; Kumar et al., 2016).

Phytopathogenic fungal diseases are mainly 

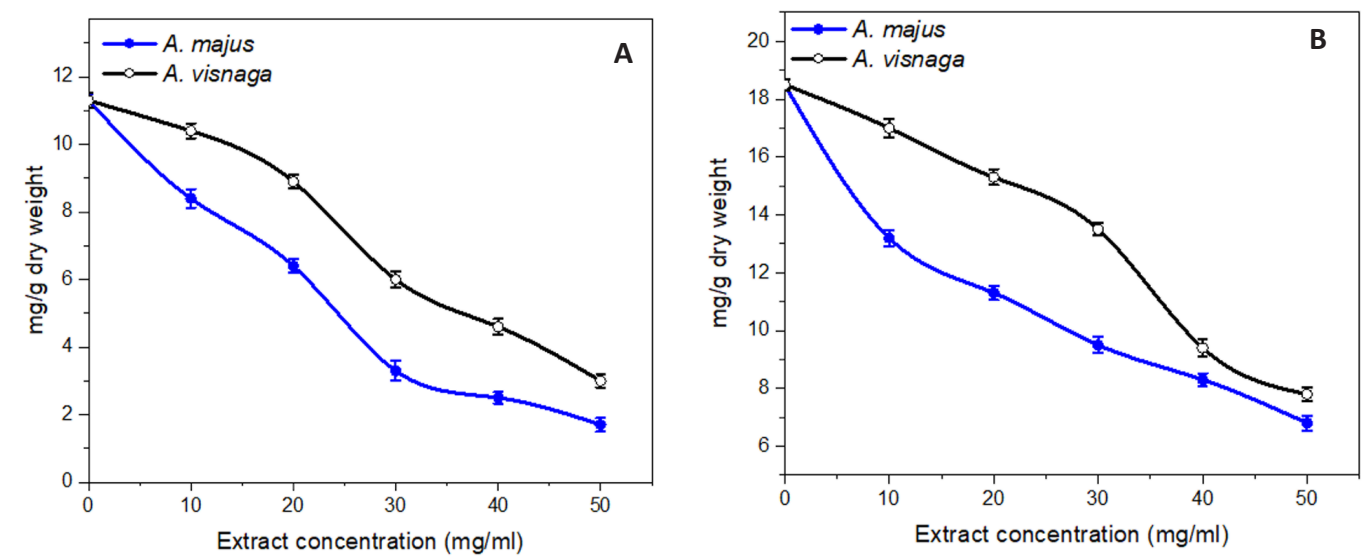

Fig. 3. Influence of aqueous leaf extracts from $A$. majus and $A$. visnagaon total amino acids (a) and total soluble protein (b) produced by $F$. oxysporum.

depending on the hydrolases and proteases which are involved in cell wall degradation, maceration and different stages in disease development. High correlation between the aggressiveness of disease and the synergistic action of various enzymes was reported (Chandrasekaran et al., 2016).
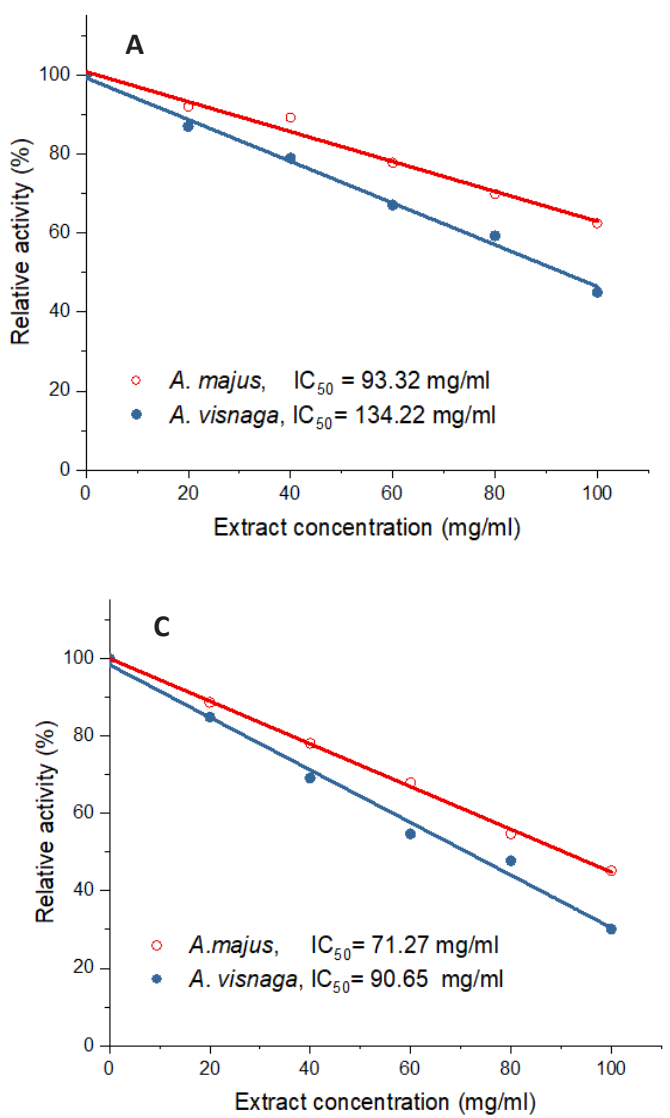

The response of the pathogenesis-related enzymes of $F$. oxysporum toward treatment with leaf extracts of $A$. majus and $A$. visnaga was investigated and the results are presented in Fig. 4. The results reveal that all studied extracellular enzymes from $F$. oxysporum were inhibited in a concentration-dependent manner. Under treatment
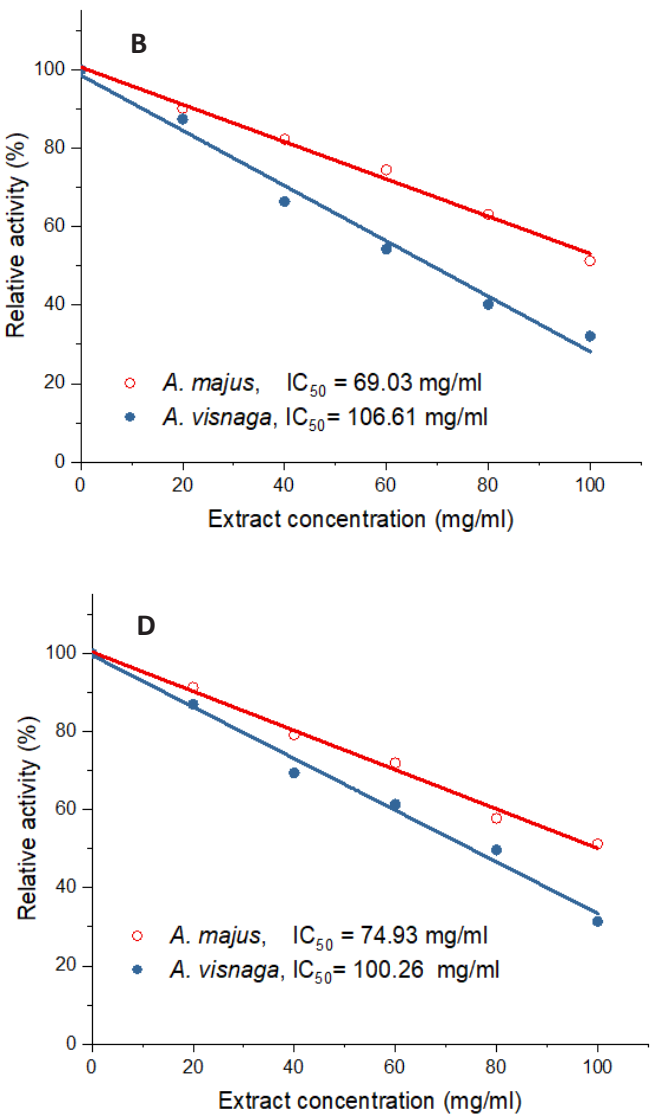

Fig. 4. Influence of leaf extracts of $A$. majus and $A$. visnaga on production of pectinase (A), protease (B), cellulase (C) and xylanase (D) by $F$. oxysporum. 
with $A$. majus leaf extract $\mathrm{IC}_{50}$ values for pectinase (Fig. 4A), protease (Fig. 4B), cellulase (Fig. 4C) and xylanase (Fig. 4D) were 93.32, 69.03, 71.27 and $74.93 \mathrm{mg} / \mathrm{ml}$, respectively. However, $\mathrm{IC}_{50}$ values were $134.22,106.31,90.65$ and $100.26 \mathrm{mg} /$ $\mathrm{ml}$ for the same enzymes in the same order under treatment with $A$. visnaga leaf extract.

Pectinases represent a determining factor in plant susceptibility toward the wilt-producing Fusarium sp. as the suppression of fungal pectinase induces resistance of plant against fungal infection (Herbert et al., 2003). Pectinase catalyzes the cleavage of glycosidic linkage causing a depolymeraization of pectins (Kashyap et al., 2001; King et al., 2002). Powell et al. (2000) suggested that the inhibition of polygalacturonase is the reason for significant reduction in virulence of Botrytis cinerea.

Xylanases have the capability to depolymerize xylan which is secondary plant cell wall polysaccharides (Wong et al., 1988). However, other researchers reported that xylanase is not essential for fungal pathogenicity (Gomez-Gomez et al., 2002; Calero-Nieto et al., 2007). It has been reported that deletion of xylanase gene expression causes significant reduction in pathogenicity (Brito et al., 2006). Interestingly, fungal xylanase may elicit the defense mechanisms in the plants (Belien et al., 2006).

It has been reported that flavonoids, phenolics and other compounds in plant leaf extracts may be the reason for the inhibition of pectinase, proteases, xylanase and cellulase activities (Mehta \& Mehta, 2005; Nayebi et al., 2013). Therefore, the total phenols and total flavonoids in the two Ammi species were determined (Fig. 5). The total phenol constituents detected in the leaf extracts of A. majus and A. visnaga were $31.4 \pm 0.8$ and $21.5 \pm 0.6 \mathrm{mg}$ GA (gallic acid) $\mathrm{g}^{-1}$ dry weight, respectively. However, the total flavonoid in leaf extracts of A. majus and A. visnaga were $19.6 \pm 0.6$ and $11.8 \pm 0.5 \mathrm{mg}$ QE (quercetin equivalent) $\mathrm{g}^{-1}$ dry weight. These results are in harmony with those of Hussein et al. (2016) who found the presence of secondary phenolic constituents in A. majus. Furthermore, the phenolics and flavonoids of $A$. visnaga were in the range of 18.66 to $172.66 \mathrm{mg}$ $\mathrm{GAg}^{-1}$ and 3.3 to $22 \mathrm{mg} \mathrm{QE} \mathrm{g}{ }^{-1}$, respectively (Belkacem et al., 2016).

The presence of phenols and flavonoids in Ammi plants reveal and confirm that these compounds seems likely to play an important part in the inhibition of cell wall degrading enzymes of F. oxysporum. Surendran et al. (2018) reported a

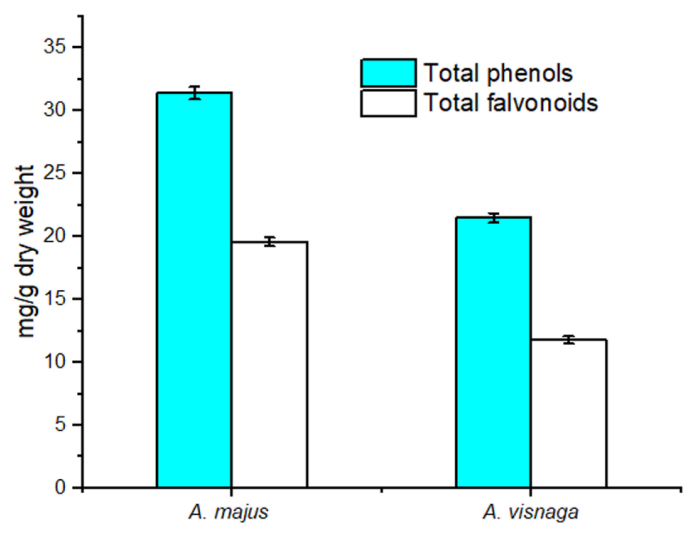

Fig. 5. The contents of total phenol and the total flavonoid in $A$. majus and $A$. visnaga.

remarkable inhibition of cellulase of Ganoderma sp. by different phenolic compounds. The degree of inhibition of cellulase and polygalacturonase by phenolics was concentration-dependent (Mehta \& Mehta, 2005). Furthermore, it was reported that various phenolics inhibited the activity of cell wall degrading enzymes of $F$. oxysporum (Modafar \& Boustani, 2001).

Since leaf extracts of Ammi plants contains remarkable content of phenol, their toxicity mechanism against $F$. oxysporum may include interference with cell wall synthesis, changing the permeability of cell, interfering with the electron transport, the nutrient absorption, the ATP production, metabolic processes of the cell, inactivation of differnt enzymes in the cells and protein denaturation (Marjorie, 1996; Al-Amiery et al., 2012). Furthermore, studies have indicated that the hydroxyl groups of phenol are responsible for the toxicity against microorganisms. This implies that increased hydroxylation leads to increased toxicity. It seems likely that phenolic toxicity to microbial enzymes is possibly through reaction with sulfhydryl group throught nonspecific interactions with membrane proteins (Arif et al., 2009).

\section{Conclusion}

The findings of the present study lead to the conclusion that the aqueous leaf extracts from both A. majus and A. visnaga have antifungal activity against the wilt-producing $F$. oxysporum . 
The leaf extracts caused remarkable reduction in the growth of $F$. oxysporum, the activities of the different metabolic enzymes, pathogeneicty related enzymes, total amino acids and total soluble protein. The present work presents beneficial information for developing of natural eco-friendly and inexpensive formulations using Ammi leaf extracts for protection of tomato against F. oxysporum. However, more studies are required to explain the crucial mechanisms of the fungal inhibition by Ammi leaf extracts and to determine the compounds responsible for the inhibition which seems likely complex and multifactorial.

\section{References}

Adham, A., Abdula, Z. (2017) Antibacterial and antibiofilm activity of Ammi majus seed against Gram-positive bacteria. Journal of Medicinal Science, 21(1), 1-8.

Aguillar, G., Huitron, C. (1990) Constitutive exopectinase produced by Aspergillus sp. CH-Y1043 on different carbon sources. Biotechnology Letters, 12, 655-660.

Al-Amiery, A.A., Kadhum, A.A., Mohamad, A.B. (2012) Antifungal activities of new coumarins. Molecules, 17, 5713-5723.

Al-Hadhrami, R.M., Al Muniri, R.M., Hossain, M.A. (2016) Evaluation of antimicrobial and cytotoxic activities of polar solvent extracts from leaves of Ammi majus used by the omanis. Pacific Science Review, 18(1), 62-65.

Al-Snafi, A. (2013) Chemical constituents and pharmacological activities of Ammi majus and Ammi visnaga. A review. International Journal of Pharmceutical and Industerial Research, 3(3), 257 265.

Aourabi, S., Driouch, M., Sfaira, M., Mahjoubi, F., Hammouti, B., Emran, K.M. (2019) Influence of phenolic compounds on antioxidant and anticorrosion activities of Ammi visnaga extracts obtained ultrasonically in three solvent systems. International Journal of Electrochemical Science, 14, 6376-6393.

Arif, T., Bhosale, J.D., Kumar N., Mandal, T.K., Bendra, R.S., Lavekar, G.S., Dabur, R. (2009) Natural products: Antifungalagents derived from plants. Journal of Asian Natural Products Research, 11(7),
$621-638$

Bailey, M., Biely, P., Poutanen, K. (1992) Interlaboratory testing of methods for assay of xylanase activity. Journal of Biotechnology, 23(3), 257-270.

Belien, T., Van Campenhout., S., Robben., J., Volckaert., G. (2006) Microbial endoxylanases: Effective weapons to breach the plant cell wall barrier or, rather, triggers of plant defense systems? Molecular Plant-Microbe Interactions, 19, 1072-1081.

Belkacem, I., Ouafa, R., Rachid, D. (2016)Antimicrobial and antioxidant activity of Ammi visnaga (L) phenolic extracts and their effects on planktonic and biofilm growth of food spoilage Bacillus cereus. International Journal of Bioscience, 9(4), 32-47, 2016.

Betke, K., Beutler, E., Brewer, G.J., Kirkman, H.N., Luzzatto, L., Motulsky, A.G., Ramot, B., Siniscolo, M. (1967) Standardisation of procedures for the study of glucose-6-phosphate dehydrogenase. Report of a WHO scientific group. WHO Technical Report Series, 366, 1-53.

Bradford, M. (1976) A rapid and sensitive method for the quantitation of microgram quantities of protein utilizing the principle of protein-dye binding. Analalytical Biochemistry, 72, 248-254.

Brito, N., Espino, J.J., Gonzalez, C. (2006) The endo$\beta$-1,4-xylanase Xyn11A is required for virulence in Botrytis cinerea. Molecular Plant Microbe Interaction, 19, 25-32.

Calero-Nieto, F., Di Pietro, A., Roncero, M.G., Hera C. (2007) Role of the transcriptional activator $\mathrm{X} \ln \mathrm{R}$ of Fusarium oxysporum in regulation of xylanase genes and virulence. Molecular Plant Microbe Interaction, 20(8), 977-985.

Chamizo-Ampudia, A., Sanz-Luque, E., Lamas, A., Galvan, A., Fernandez, E. (2017) Nitrate reductase regulates plant nitric oxide homeostasis. Trends in Plant Science, 22, 163-174.

Chandrasekaran, M., Thangavelu, B., Chun, S.C., Sathiyabama, M. (2016) Proteases from phytopathogenic fungi and their importance in phytopathogenicity. Journal of General Plant Pathology, 82, 233-239.

Chen, J.Y., Wen, P.E., Kong, W.F., Pan, Q.H., Zhan, 
G.C., Li, J.M., Wan, S.B., Huang, W.D. (2006) Effect of salicylic acid on phenylpropanoids and phenylalanine ammonia lyase in harvested grape berries. Postharvest Biology and Technology, 40, 64-72.

Dwivedi, S.K., Sangeeta, S. (2015) Efficacy of some medicinal plant extract against Fusarium oxysporum f. sp. ciceri causing chickpea wilt. Asian Journal of Crop Science, 7(2), 138-146.

El-Shora, H.M., Khalaf, S.A. (2008) Activities and kinetic characteristics of glutaminesynthetase from Penicillium cyclopium. Annals of Microbiology, 58, 691-696.

El-Shora, H.M., Metwally, A.M. (2008) Production, purification and characterisation of proteases from whey by some fungi. Annals of Microbiology, 58, 495-502.

El-Shora, H.M., Ali, A.S. (2011) Changes in activities of nitrogen metabolism enzymes in cadmium stressed marrow seedlings. Asian Journal of Plant Sciences, 10, 117-124.

El-Shora, H.M., Abou-El-Wafa, G.S., Kadhim, A.I (2016) Purification and biochemical characteristic of protease from the red seaweed Petrocladia capillacea. International Journal of Current Microbiology and Applied Sciences, 5(2), 297-308.

El-Shora, H.M., El-Amier, Y.A., Awad, M. H. (2019) Antimicrobial activity and allelopathic potential of Zygophyllum coccineum L. on Chenopodium album L. British Journal of Applied Science \& Technology, 15(5), 1-10.

Evans, H.J., Nason, A. (1953) Pyridine nucleotidenitrate reductase from extracts of higher plants. Plant Physiolology, 28, 233-254.

Forde, B.G., Lea, P.J. (2007) Glutamate in plants: Metabolism, regulation, and signalling. Journal of Expirmental Botany, 58(9), 2339-2358.

Fu, F., Zhang, Z., Shu, Y. (2018) Putative connections between nitrate reductase S-Nitrosylation and NO synthesis under pathogen attacks and abiotic stresses. Frontiers in Plant Scince, 9, 1-6.

Gholamnezhad, J. (2019) Effect of plant extracts on activity of some defense enzymes of apple fruit in interaction with Botrytis cinerea. Journal of
Integrative Agriculture, 18(1), 115-123.

Goel, A., Sharma, K. (2016) Effect of Euphorbia pulcherrima leaf extract on secretion of microbial extracellular enzymes. Journal of Biological and Chemical Research, 33(2), 944-951.

Goel, N., Patra, R., Verma, S.K., Sharma, P.C. (2019) Purification and characterization of cellulase from Pseudomonas sp. isolated from waste dumping site soil. Journal of Applied Biotechnology and Bioengineering, 6(3), 118-124.

Gomez-Gomez, E., Ruiz-Roldan, M.C., Pietro, A.D., Roncero, M.I.G., Hera, C. (2002) Role in pathogenesis of two endo- $\beta$-1,4-xylanase genes from the vascular wilt fungus Fusarium oxysporum. Fungal Genetics and Biology, 35, 213-222.

Gulati, V., harding, I., Palombo, E. (2012) Enzyme inhibitory and antioxidant activities of traditional medicinal plants: Potential application in the management of hyperglyacemia. $B M C$ Complementary and Alternative Medicine, 12, 1-9.

Gupta, V.K., Sharma, R.C. (2008) Integrated management of soil-borne diseases. In: "Advances in Soil Borne Plant Diseases", Manjunath, N. and G.S.D. Rani (Eds.), pp.415-427. New India Publishing Agency, New Delhi, India.

Hall, N., Tomsett, A.B. (2000) Structure-function analysis of NADPH: Nitrate reductase from Aspergillus nidulans: Analysis of altered pyridine nucleotide specificity in vivo. Microbiology, 146, 1399-406.

Hadizadeh, I., Peivastegan, B., Kolahi, M. (2009) Antifungal activity of Nettle (Urtica dioica L.) colocynth (Citrullus colocynthis L. Schrad), Oleander (Nerium oleander L.) and Konar (Ziziphus spina-christi L.) extract on plants pathogenic fungi. Pakistan journal of Biological Science, 12(1), 5863.

Hashim, S., Jan, A., Marwat, K., Khan, M. (2014) Phytochemistry and medicinal properties of Ammi visnaga (Apiacae). Pakistan Journal of Botany, 46(3), 861-867.

Herbert, C., Boudat, G., Borel, C., Esquerre-Tugaye, M., Dumas, B. (2003) Regulation and role of pectinase in phytopathogenic fungi. In: "Advances in Pectin and Pectinase Research", Voragen, F., 
Schols, H. and Visser, R. (Eds.). DOI:10.1007/97894-017-0331-4_15.

Hussein, H., Hameed, I., Ubaid, J. (2016) Analysis of the secondary metabolite products of Ammi majus and evaluation anti-insect activity. International Journal of Pharmacognosy and Phytochemical Research, 8(8), 1403-1411.

Hyun, M.W., Yun, Y.H., Kim, J.Y., Kim, S.H. (2011) Fungal and plant phenylalanine ammonia-lyase. Mycobiology, 39, 257-265.

Juge, N. (2006) Plant protein inhibitors of cell wall degrading enzymes. Trends in Plant Science, 11, 359-367.

Kaboodi, P.S., Moghadamnia, A.A., Bakhshi, D., Sefidgar, A.A. (2016) A study of phytochemical properties of variousextracts of Ammi majus fruit using GC-MS technique. Ecology, Environment and Conservation, 23(1), 150-155.

Kashyap, D.R., Vohra, P.K., Chopra, S., Tewari, R. (2001) Applications of pectinases in the commercial sector: A review. Bioresource Technology, 77, 215227.

Kaur, C., Kapoor, H.C. (2002) Antioxidant activity and total phenolic content of some Asian vegetables. International Journal of Food Science and Technology, 37, 178-182.

Kilani-Jaziri, S., Bhouri, W., Skandrani, I., Limem, I., Chekir-Ghedira, L., Ghedira, K. (2011) Phytochemical, antimicrobial, antioxidant and antigenotoxic potentials of Cyperus rotundus extracts. South African Journal of Botany, 77, 767776.

King, M.R., White, B.A., Blaschek, H.P., Chassy, B.M., Mackie, R.I., Cann, I.K.O. (2002) Purification and characterization of a thermostable $\alpha$-galactosidase from Thermoanaerobacterium polysaccharolyticum. Journal of Agricultural and Food Chemistry, 50, 5676-5682.

Kolbert, Z., Bartha, B., Erdei, L. (2008) Exogenous auxin-induced NO synthesis is nitrate reductaseassociated in Arabidopsis thaliana root primordia. Journal of Plant Physiology, 165, 967-975.

Kubicek, C.P., Starr, T.L., Glass, N.L. (2014) Plant cell wall-degrading enzymes and their secretion in plant-pathogenic fungi. Annual Review of Phytopathology, 52, 427-451.

Kumar, Y., Zhang, L., Panigrahi, P., Dholakia, B.B., Dewangan, V., Chavan, S.G., Kunjir, S.M., Wu, X., Li, N., Rajmohanan, P.R., Kadoo, N.Y., Giri, A.P., Tang, H., Gupta, V.S. (2016) Fusarium oxysporum mediates systems metabolic reprogramming of chickpea roots as revealed by a combination of proteomics and metabolomics. Plant Biotechnology Journal, 14, 1589-1603.

Macheda, M.L., Hynes, M.J., Davis, M.A. (1999) The Aspergillus nidulans gltA gene encoding glutamate synthase is required for ammonium assimilation in the absence of NADP-glutamate dehydrogenase. Current Genetics, 34(6), 467-71.

Maninegalai, V., Ambikapathy,V., Panneerselvam, A. (2011) Antifungal potentiality of some medicinal plants extracts against Bipolaris oryzae (Breda de Haan). Asian Journal of Plant Science Research, 1, $77-80$.

Marjorie, C. (1996) Plant products as antimicrobial agents. Clinical Microbiology Reviews, 12, 564 582.

Mehta, A., Mehta, P. (2005) Antifungal potency of plant stem extract on growth, pectolytic and cellulolytic enzymes production and rot development on grapes by Geotrichum candidum. Journal of Mycology and Plant Pathology, 35, 156-158.

Modafar, C.E., Boustani, E.E. (2001) Cell wall bound phenolic acid and lignin contents in date palm as related to its resistance to Fusarium oxysporum. Biologia Plantarum, 44, 125-130.

Moore, S., Stein, W.H., (1948) Photometric methods for use in the chromatography of amino acids. Journal of Biological Chemistry, 176, 367-388.

Mostafa, S.A., Mahmoud, M.S., Mohamed, Z.K., Enan, M.R. (2009) Cloning and molecular characterization of chitinase from Bacillus licheniformis MS-3. Journal of General and Applied Microbiology, 55, 241-246.

Nateqi, M., Mirghazanfari, S.M. (2018) Determination of total phenolic content, antioxidant activity and antifungal effects of Thymus vulgaris, Trachyspermum ammi and Trigonella foenumgraecum extracts on growth of Fusarium solani. 
Cellular and Molecular Biology, 64(14), 39-46.

Nayebi, S., Kakeshpour, T., Hasanvand, A., Nadri, M., Monfare, S.R. (2013) Composition of volatile compounds of extract of Ammi majus from Iran by GC-MS. Journal of Science, Islamic Republic of Iran, 24(4), 335-338.

Polya, G. (2003) Inhibition of digestion and metabolism. In: "Biochemical Targets of Plant Bioactive Compounds", pp. 517-524. Taylor and Francis, London.

Powell, A., van Kan, J., Have, A., Visser, J., Greve, L.C., Bennett, A.B., Labavitch, J.M. (2000) Transgenic expression of pear PGIP in tomato limits fungal colonization. Molecular Plant Microbe Interactions, 13, 942-950.

Rongai, D., Milano, F., Scio`, E. (2012) Inhibitory effect of plant extracts on conidial germination of the phytopathogenic fungus Fusarium oxysporum. American Journal of Plant Sciences, 3(12), 16931698.

Shankaracharya, N.B., Nagalakshmi, S., Naik, J.P., Rao, L.J.M. (2000) Studies on chemical and technological aspects of a jowan (Trachyspermum ammi (L.) syn. Carum copticum Hiern) seeds. Journal of Food Science and Technology, 37, 277281.

Singh, R., Kumar, A., Pandey, N.N., Gupta, M., Kumar, P., Pande, E. (2013) In vitro evaluation of antifungal activity of aqueous extract of lemon grass (Cymbopogon citrates) against pathogenic fungi Saprolegnia parasitica isolated from endangered cold water fish Tor putitora. Journal of Ecophysiology and Occupational Health, 13, 63-66.

Srinivasa, C., Nirmala, D., Devi, K., Murthy, N., Chakrabhavi, D.M., Lakshmeeshac, T.R., Singh, B.P., Kalagatur, N.K., Niranjana, S.R., Hashem, A., Alqarawi, A., Tabassum, B., Abd-Allah, E., Nayaka, S. (2019) Fusarium oxysporum f. sp. Lycopersici causal agent of vascular wilt disease of tomato: Biology to diversity-A review. Saudi Journal of Biological Sciences, 1-10. DOI:10.1016/j. sjbs.2019.06.002.
Stéphanie, M.B., Dimah, H.Z. (2009) The importance of cytosolic glutamine synthetase in nitrogen assimilation and recycling. New Phytologist, 182, 608-620.

Surendran, A., Siddiqui, Y., Ali, N.S., Manickam, S. (2018) Inhibition and kinetic studies of cellulose- and hemicellulose-degrading enzymes of Ganoderma boninense by naturally occurring phenolic compounds. Journal of Applied Microbiology, 124, 1544-1555

Walton, J.D. (1994) Deconstructing the cell wall. Plant Physiology, 104, 1113-1118.

Wong, K., Tan, L., Saddler, J.N. (1988) Multiplicity of $\beta$-1,4-xylanase in microorganisms: functions and applications. Microbiological Reviews, 52, $305-$ 317.

Xue, C.Y., Zhou, R.J., Li, Y.J., Xiao, D., Fu, J.F. (2018) Cell-wall-degrading enzymes produced in vitro and in vivo by Rhizoctonia solani, the causative fungus of peanut sheath blight. Peer Journal, 6, 1-22.

Yamamoto-Katou, A., Katou, S., Yoshioka, H., Doke, N., Kawakita, K. (2006) Nitrate reductase is responsible for elicitin-induced nitric oxide production in Nicotiana benthamiana. Plant Cell Physiology, 47, 726-735.

Zaher, A., Boufellous, M., Ouhssine, M., Bourkhiss, B. (2019) Phytochemical screening of an Umbelliferae: Ammi visnaga L. (Lam.) in the region of sidi slimane- north-west of Morocco. Journal of Materials and Environmental Sciences, 10(10), 995-1002.

Zhang, J., Bruton, B.D., Biles, C.L. (2014) Cell wall-degrading enzymes of Didymella bryoniae in relation to fungal growth and virulence in cantaloupe fruit. European Journal of Plant Pathology, 139(4), 749-761.

Zhang, H., Liang, C., Aoki, N., Kawai, K., Takane, K., Ohsugi, R. (2016) Introduction of a fungal NADP(H)-dependent glutamate dehydrogenase (gdhA) improves growth, grain weight and salt resistance by enhancing the nitrogen uptake efficiency in forage rice, Plant Production Science, 19(2), 267-278. 


\title{
التحكم الحيوي في مرض الأبول المستحث بفظرفيوزاريوم اكسيسبوروم بواسطة مستخلصات مائية لأوراق نوعين من نبات الخلة هما الخلة البرية و الخلة البلاية
}

\author{
رياض محمد الثرقاوي(1)، حامد محمد الثوري (2) \\ (1) قسم النبات - كلية العلوم - جامعة بنها - بنها - مصر، (2) قسم النبات كلية العلوم - جامعة \\ المنصورة - المنصورة - مصر.
}

يسبب فطر فيوزاريوم اكسبسبوروم مرض الذبول لمحصول الطماطم و التحكم في نمو ونشاط الفطر باستخدام مبيدات الفطريات يؤدي إلى العديد من المشاكل البيئية. وتمثل مواد الأيض النباتية طريقة بديلة للتحكم في نثاط الفطر حيث أن لها تأثير طفيف على البيئة. لذلك هدف هذا البحث إلى محاولة استخدام مستخلصات مائية لأوراق نو عين من نبات الخلة هما الخلة البرية و الخلة البلاية و المنتمي للفصيلة الخيمية. أدت معاملة الفطر بالمستخلصات المائية لأوراق نباتي الخلة إلى نثبيط

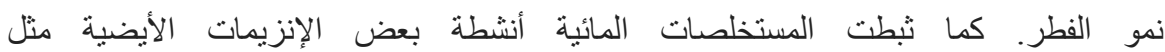

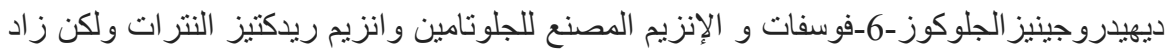

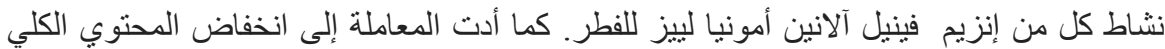
اللأحماض الأمينية الحرة والمحتوي الكلي للبروتينات الذائبة للفطر. وثبطت المستخلصات المائية أنثطة بعض الإنزيمات التي تثارك في حدوث مرض الذبول مثل البكتينيز والبروتييزو السيليوليز و الزيلانيز. تم دراسة المحتوي الكلي للفينو لات و الفلافونويدات في مستخلصات أوراق نباتي الخلة وكان محتوي كل منهما أعلى في نبات الخلة البرية عن نظيره الموجود في نبات الخلة البلدية. تقترح هذه الدراسة إمكانية استخدام المستخلصات المائية لنباتي الخلة في قمع نشاط ونمو فطر فير

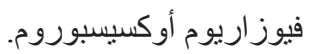

